\title{
Invasion trajectory of Pacific oysters in the northern Wadden Sea
}

\author{
Karsten Reise $^{1} \mathbb{D} \cdot$ Christian Buschbaum $^{1} \cdot$ Heike Büttger $^{2} \cdot$ Johannes Rick $^{1} \cdot$ \\ K. Mathias Wegner ${ }^{1}$
}

Received: 14 October 2016 / Accepted: 9 February 2017 / Published online: 6 March 2017

(C) The Author(s) 2017. This article is published with open access at Springerlink.com

\begin{abstract}
Invasion trajectories of introduced alien species usually begin with a long establishment phase of low abundance, often followed by exponential expansion and subsequent adjustment phases. We review the first 26 years of feral Pacific oysters Crassostrea gigas around the island of Sylt in the Wadden Sea (North Sea, NE Atlantic), and reveal causal conditions for the invasion phases. Sea-based oyster farming with repeated introductions made establishment of feral oysters almost inevitable. Beds of mussels Mytilus edulis on mud flats offered firm substrate for attachment and ideal growth conditions around low tide level. $C$. gigas mapped on to the spatial pattern of mussel beds. During the 1990s, cold summers often hampered recruitment and abundances remained low but oyster longevity secured persistence. Since the 2000s, summers were often warmer and recruitment more regular. Young oysters attached to adult oysters and abundances of $>1000 \mathrm{~m}^{-2}$ were achieved. However, peak abundance was followed by recruitment failure. The population declined and then was also struck by ice winters causing high mortality. Recovery was fast $\left(>2000 \mathrm{~m}^{-2}\right)$ but then recruitment failed again. We expect adjustment phase will proceed with mean abundance of about $1000 \mathrm{~m}^{-2}$ but density-dependent (e.g., diseases) and density-independent (e.g., weather anomalies)
\end{abstract}

Responsible Editor: M. G. Chapman.

Reviewed by B. W. Hansen, J. Ruesink and undisclosed experts.

Karsten Reise

karsten.reise@awi.de

1 Alfred Wegener Institute, Helmholtz Centre for Polar and Marine Research, Wadden Sea Station Sylt, Hafenstr. 43, 25992 List, Bremerhaven, Germany

2 BioConsult SH, Schobüller Str. 36, 25813 Husum, Germany events causing strong fluctuations. With continued global warming, feral $C$. gigas at the current invasion fronts in British estuaries and Scandinavian fjords may show similar adjustment trajectories as observed in the northern Wadden Sea, and also other marine introductions may follow the invasion trajectory of Pacific oysters.

\section{Introduction}

Transfers of marine organisms in the wake of expanding global markets and seafaring are increasingly changing the species compositions along coasts (Rilov and Crooks 2009). Whether nonnative species become established at a distant coast depends on frequency and magnitude of introductions (propagule pressure sensu Johnston et al. 2009), on invasive traits, on physiological matches with and adaptations to environmental conditions, and on the invasibility of recipient ecosystems (Olyarnik et al. 2009). Invasions often proceed through a prolonged lag phase before exponential population growth commences (Crooks 2005; Crooks and Rilov 2009). Eventually growth will stop and population abundance decline again (Simberloff and Gibbons 2004). How prevalent such patterns are in marine ecosystems will require more detailed long-term studies on invasions stemming from various organismal groups (Lockwood and Robinson 2014).

To compare invasion trajectories between populations or species, Reise et al. (2006) suggested an empirical scheme of three phases: after one or more introduction events, an establishment phase of low abundance and minor spread may linger on for several generations. It may be followed by exponential expansion phase leading to dominance with strong impacts. The subsequent adjustment phase begins with behavioral and evolutionary adaptations to abiotic and 
biotic conditions and can be described by three categories (Fig. 1).

If invaders remain rather unaffected by enemies (e.g., due to counter adaptations or newly arriving enemies), the achieved dominance can become permanent (type I). The clam Mya arenaria in European estuaries (Strasser 1999) or the Mediterranean mussel Mytilus galloprovincialis at rocky shores in South Africa (Branch and Steffani 2004) are good examples. Most invaders, however, undergo strong fluctuations in abundance and population size in the course of the adjustment phase (type II). They may even fail to recover from bust after initial boom (type III), e.g., the comb jelly Mnemiopsis leidyi in the Black Sea (Bilio and Niermann 2004) and the polychaete Marenzelleria viridis in the Wadden Sea (Essink and Dekker 2002).

We here present a case study of the first 26 years since initial spread of Pacific oysters Crassostrea gigas (Thunberg 1793) in the northern Wadden Sea (eastern North Sea). Although $C$. gigas was introduced from a Scottish hatchery since 1971 on a small scale (Drinkwaard 1999a), a feral population only established after 1986 when commercial oyster farming imported annually about 1 million halfgrown Pacific oysters from an Irish nursery which in turn received oyster spat from British hatcheries. These oysters are kept in net bags tied to trestles positioned at low tide level, and in winter are usually stored indoors to avoid damage by ice and storms. Public concern about introducing an exotic oyster into the Wadden Sea National Park were overcome by assuring that North Sea waters would be too cold for reproduction. This was contrary to the facts already known at that time (Drinkwaard 1999b; Troost 2010), and a feral population of $C$. gigas established, expanded exponentially and then entered an adjustment phase.

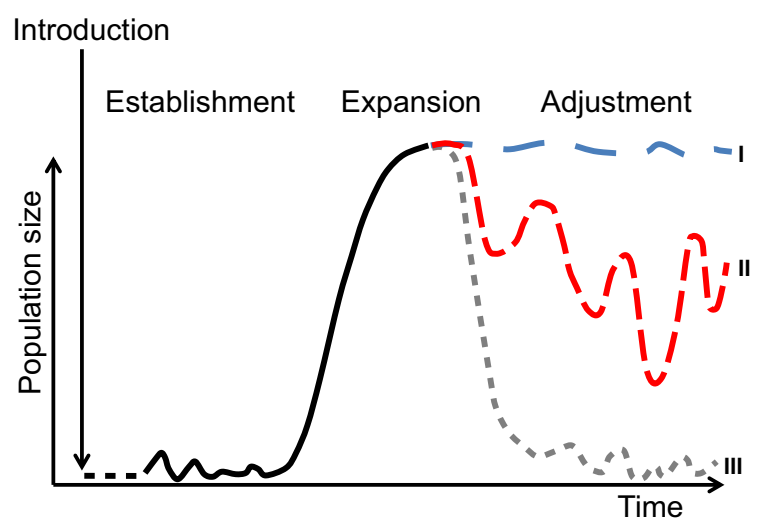

Fig. 1 Invasion trajectories after one or more introductions with consecutive establishment, expansion and adjustment phase. Dominance may be maintained during the latter phase (type I), strong fluctuations may be caused by environmental, intrinsic and enemy effects (type II) or rarity prevails after boom and bust (type III)
By comparing the first 26 years of feral development with oyster invasions at other coasts, we make an attempt to reveal main factors shaping the dynamics of this population in relation to the relative roles of invasive traits and recipient conditions. For initial phases we can ask what facilitated or inhibited establishment and expansion, while later phases of the invasion can indicate what has stopped the population boom. Answering such questions and providing details from closely monitored invasion processes might provide the necessary data to develop a general model of marine invasions that can be used to implement proper management. In particular, we urge to extend more studies beyond expansion phase to improve understanding and evaluation of biological invasions. The ultimate question will be whether the adjustment phase should be regarded as a general invasion characteristic or more as a specific outcome of life history characteristics and the contingencies of species interactions and environmental variability in the recipient region.

\section{Methods}

In this analysis of the Crassostrea gigas invasion since first feral oysters were found near the island of Sylt, we combine (1) the results of an initial assessment of the population in the northern and southern tidal basins at the lee side of Sylt after the first 6 years (see Fig. 2; Reise 1998), with (2) subsequent investigations by Diederich (2005a, b, 2006), Diederich et al. (2005), Nehls et al. (2006), Büttger et al. (2011), Kochmann et al. (2008), Eschweiler (2011) and Moehler et al. (2011) on this regional oyster invasion, and (3) new field data collected on a yearly basis until 2016.

These annual oyster counts were conducted between August and September on mussel beds near Munkmarsch harbor, $5 \mathrm{~km}$ south from the oyster farm (Fig. 2). This coherent cluster of mussel beds was visited for counting in 1995, 1999 and regular sampling was done from 2001 to 2016. Total sample area per year varied from $0.24 \mathrm{~m}^{2}$ with 6 replicates in 2014 to $28.65 \mathrm{~m}^{2}$ with 129 replicates in 2001, depending on oyster density and returning tide (Table 1). Assessments of abundances were done during low tide. Depending on oyster density, quadrats of 0.04 to 1 $\mathrm{m}^{2}$ (mostly $0.04 \mathrm{~m}^{2}$ ) were randomly placed on mussel beds and later on oyster reefs, as oyster density increased. Sampling was stratified with counts confined to areas covered by epibenthic bivalves, whereas bare patches were avoided. At high density, oysters and mussels (Mytilus edulis) were collected and washed through a 1-mm mesh sieve before counting. To maximize the number of samples, oyster spat $<20 \mathrm{~mm}$ were not counted because these were hard to detect when attached to adult oysters. 


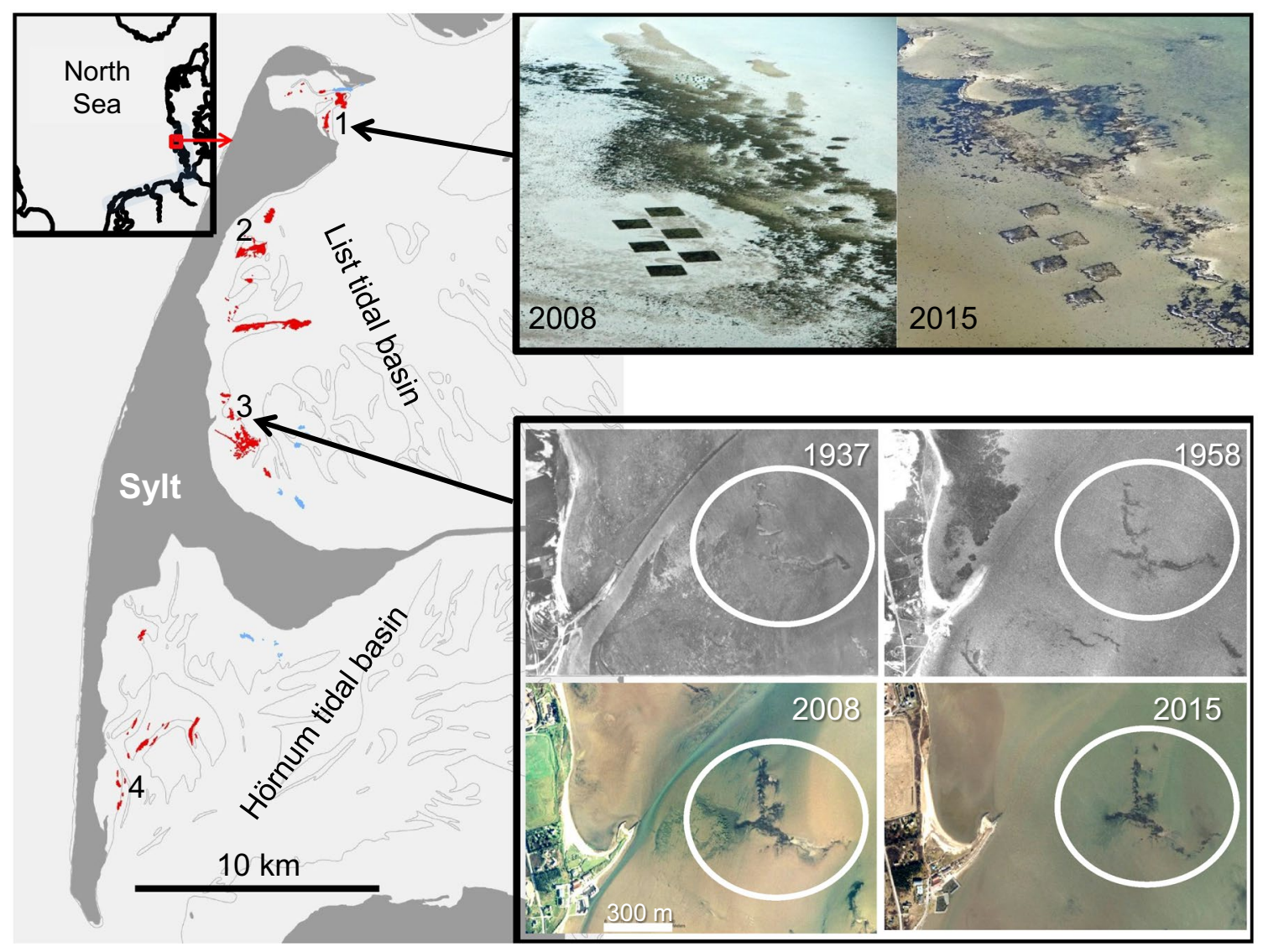

Fig. 2 Intertidal beds dominated by oysters (dark/red) and mussels (light gray/blue) in terms of total wet weight or cover in 2013 in the tidal basins sheltered by the island of Sylt (for position see inset upper left), drawn from aerial photographs and by visiting almost all beds on the ground. Thin line indicates mean low tide level. Locations mentioned in the text: 1 Königshafen, 2 Oyster farm, 3 Munkmarsch, 4 Puan Klent. Upper right: Aerial views of experimental beds in Königshafen on a lugworm flat near a wild bed of mussels and oysters. From 2 months after initiation in 2008 (left) to 8 years

Although oyster spat was not counted in this survey, qualitative observations on the occurrence of oyster spat were made throughout the tidal basins. Spat distribution was very patchy and categorized as 'absent' when in autumn none or only small numbers were found, 'present' when variable numbers were observed at $>3$ sites, and 'abundant' when encountered at almost all beds in high numbers. We tested the influence of summer temperature (mean and maximum temperature recorded in July and August during cruises for plankton monitoring carried out by the Wadden Sea Station Sylt) on observing a spatfall event by binomial generalized linear models (GLM) with logit link function. Likelihood ratio tests were used to assess significance of the effects of mean and maximum temperature.

To validate our on site assessment, we compared rapid field counts with careful counting of nine $0.04-\mathrm{m}^{2}$ later the square-cut beds have hardly changed except minor losses in winter. Color intensity varied with algal cover, and on bare sediment with tube caps of the polychaete Lanice conchilega abundant in 2008 and wave erosion in 2015. Lower right mussel beds near Munkmarsch harbor on aerial photographs taken at low tide long before (upper row) and after (lower row) Pacific oysters took over. Aerial appearance varies more with picture quality and low tide conditions than with size and shape of the biogenic structure. The annually sampled beds are encircled

samples from reefs with a high proportion of small oysters in the laboratory. We found that field counts underestimated oyster abundance by $12 \%$ and that of mussels by $6 \%$. Thus, field counts should be taken as proxies of oyster abundances. Shell size was measured in the field to nearest 5-mm interval. Although shapes of oysters could vary considerably, for simplicity only the longest diameter (from umbo to farthest shell edge) was recorded.

To investigate potential habitat expansion during the later stages of the invasion we checked for subtidal colonization. The shallow subtidal zone (to $1 \mathrm{~m}$ below mean low tide level) was investigated by wading during exceptional low tides when offshore winds and spring tides coincided. Deeper zones were investigated by dredging ( $1 \mathrm{~m}$ width of metal blade, meshes of $10-20 \mathrm{~mm}$; built after Fig. 3 in Möbius 1877). Depth was measured 
Table 1 Sampling of Crassostrea gigas $\geq 20 \mathrm{~mm} \varnothing$ on mussel beds near Munkmarsch harbor (see Fig. 2). Sample size and method (nondestructive visual inspection or picking epibenthos by hand and washed over a 1-mm mesh) was adapted to oyster density. Occasionally the returning tide curtailed the number of replicates

\begin{tabular}{|c|c|c|c|c|}
\hline Month-Year & $\begin{array}{l}\text { Size of } \\
\text { samples } \\
\left(\mathrm{m}^{2}\right)\end{array}$ & $\begin{array}{l}\text { Number } \\
\text { of sam- } \\
\text { ples }\end{array}$ & $\begin{array}{l}\text { Total } \\
\text { sample size } \\
\left(\mathrm{m}^{2}\right)\end{array}$ & Method \\
\hline 08-1993 & 1.00 & 485 & 485 & Visual \\
\hline 07-1995 & 0.25 & 32 & 8.0 & Visual \\
\hline 09-1999 & 0.25 & 126 & 31.5 & Visual $^{\mathrm{a}}$ \\
\hline $07-2001$ & 0.25 & 90 & 22.5 & Visual $^{\mathrm{b}}$ \\
\hline 07-2001 & 0.16 & 40 & 6.4 & Visual $^{\mathrm{b}}$ \\
\hline 09-2002 & 0.25 & 40 & 10 & Visual \\
\hline 08-2003 & 0.04 & 75 & 3.0 & Visual \\
\hline 09-2004 & 0.04 & 70 & 2.8 & Visual \\
\hline 09.2005 & 0.04 & 40 & 1.6 & Visual \\
\hline 09-2006 & 0.04 & 40 & 1.6 & Visual, 6 sieved \\
\hline 09-2007 & 0.04 & 30 & 1.2 & Sieved \\
\hline 09-2008 & 0.04 & 14 & 0.56 & Sieved \\
\hline 09-2009 & 0.04 & 16 & 0.64 & Sieved \\
\hline $07+09-2010$ & 0.04 & 34 & 1.36 & Sieved \\
\hline 09-2011 & 0.04 & 8 & 0.32 & Visual \\
\hline 09-2012 & 0.04 & 10 & 0.40 & Sieved \\
\hline 09-2013 & 0.04 & 8 & 0.32 & Sieved \\
\hline 08-2014 & 0.04 & 6 & 0.24 & Sieved \\
\hline 09-2015 & 0.04 & 7 & 0.28 & Sieved \\
\hline 07 to $09-2016$ & 0.04 & 8 & 0.32 & Sieved \\
\hline
\end{tabular}

${ }^{a}$ From Diederich et al. (2005)

${ }^{\mathrm{b}}$ These data are combined in Fig. 3 with weighed means and variation

relative to actual low tide level (http://www.bsh.de/aktdat/bm/Baden\&Meer.htm) from nearest tide gauge.

Six experimental oyster plots of $10 \times 10 \mathrm{~m}$ were set up on a lugworm flat in the eastern part of Königshafen on the landward (sheltered) side of a mixed wild bed with mussels and oysters by collecting scattered clumps of oysters in June/July 2008 (Fig. 2, upper part). Bare sediment was completely covered at experimental plots to measure effects of beds on sediment benthos relative to uncovered areas in between. Here we only compare plot area between 2008 and 2016. Together with aerial surveys on long-term position, size and shape of beds (Büttger et al. 2014 and see Fig. 2, lower part) we use these data to evaluate bed consistency over time. On this basis we assumed a constant area of $0.3 \mathrm{~km}^{2}$ of mudflats covered by beds of mussels and oysters (area estimate from Reise and Lackschewitz 1998 and Lackschewitz et al. 2002; neglecting the small Danish sector of the northern tidal basin). This area size was used when extrapolating abundance data obtained at the Munkmarsch beds (see above) to total oyster population size in the Sylt tidal basins.

\section{Results}

\section{Establishment of Pacific oysters in the northern Wadden Sea}

Four years after the farm started production of Pacific oysters on the island of Sylt, breeding and subsequent larval dispersal led to first settlement of feral Crassostrea gigas (Fig. 3). In 1991, two young oysters were found 6 to $8 \mathrm{~km}$ away from the farm, attached to valves of Mytilus edulis and Mya arenaria. Diameters were 40 and $48 \mathrm{~mm}$, suggesting settlement in summer 1990 (Reise 1998). Since then, feral oysters have been found every year. Mussel beds offered the necessary firm substrate for larval metamorphosis and happened to occur at positions which provide optimal conditions for feral Pacific oysters to thrive. In 1995, a first survey was conducted in the List and Hörnum tidal basins of Sylt to assess the extent of spread. All 21 intertidal mussel beds of the area were visually inspected and oysters were detected at 17 with an average density of 2-3 oysters $\mathrm{m}^{-2}$. Most were 20 to $40 \mathrm{~mm}$ in length and had presumably settled in 1994. The largest oyster was $114 \mathrm{~mm}$ and probably had settled in 1990. At that time, no Pacific oysters were encountered in the subtidal zone by dredging. Some oysters were found at harbor walls and shore revetments but the majority was confined to mussel beds. The size of the feral population in 1995 was approximately 1 to 2 million oysters on $0.3 \mathrm{~km}^{2}$ mud flats completely covered by mussels. Thus, the size of the feral population was similar to the number of $C$. gigas reared in the farm.

Pacific oysters established on mussel beds about $\pm 0.7 \mathrm{~m}$ relative to mean low tide level. Uppermost $C$. gigas were not exceeding $4 \mathrm{~h}$ of average low tide exposure during semi-diurnal tides. From 1999 onwards, dredge hauls at 1 to $10 \mathrm{~m}$ depth below mean low tide level caught scattered clumps of Pacific oysters. Such stray clumps were also encountered throughout the intertidal zone. Based on this general distribution pattern, we regard the monitored beds near Munkmarsch harbor as sufficiently representative for extrapolating estimated abundances to the entire population size and dynamics of $C$. gigas in the Sylt tidal basins.

\section{Abundance}

Near Munkmarsch harbor a coherent cluster of mussel beds occurred around low tide level covering 2 to 3 ha of mud (Fig. 2). Mussel beds have been known from this site for about 80 years. The establishment phase of $C$. gigas began in the early 1990s (Reise 1998). Abundances remained rather low until 2001 (Fig. 3). From 2001 onwards rapid population growth commenced. Within 7 years abundances of more than $1500 \mathrm{~m}^{-2}$ were reached. Although oysters became structurally dominant on former mussel beds since 


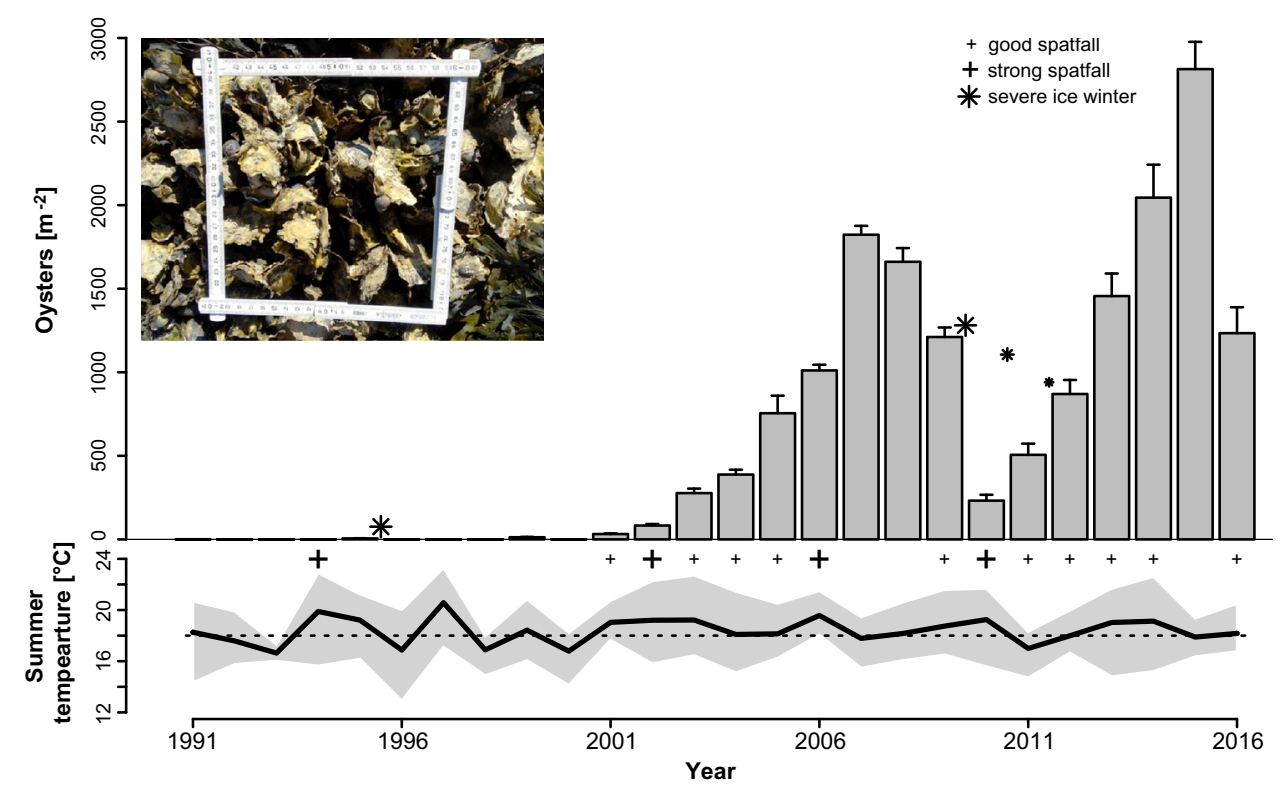

Fig. 3 Upper panel abundance of Crassostrea gigas $(\geq 20 \mathrm{~mm}) \mathrm{m}^{-2}$ on mussel beds near Munkmarsch (see Fig. 2) from 1993, 1995, 1999 and 2001 to 2016, counted between July and September (see Table 1). Columns refer to means and vertical bars to standard error. ' + ' indicates spat of the year was present and ' + ' a particularly abundant spat fall of oysters $(<20 \mathrm{~mm})$. Ice winters were very severe in $1995 / 1996$ and 2009/2010 and modest in 2010/2011 and 2011/2012 (size of $*$ indicates relative duration of ice cover). Inset shows sample size of

2004, beds remained remarkably similar in size and shape (Fig. 2), indicating that Pacific oysters required the substratum of mussel beds. Assuming bed area remained constant in the two tidal basins, and densities on Munkmarsch beds were representative, population size in the two tidal basins increased to half a billion $\left(0.5 \times 10^{9}\right)$ in 2007 and about one billion in 2015.

\section{Recruitment}

Spawning was usually observed in late July, larvae mainly in August and spat $<2 \mathrm{~mm}$ was found from late August to October. Recruitment did not occur every year. A first strong spat fall apparently happened in 1994. This was not observed directly but can be inferred from abundant young oysters (20 to $70 \mathrm{~mm}$ ) found in summer 1995 (Fig. 4). Since the oyster farm was established, oyster spat falls occurred in years with July-August mean temperatures exceeding $18^{\circ} \mathrm{C}$ (in 6 years from 1987 to 2003; Diederich et al. 2005). In subsequent years, mean summer temperatures were almost always above $18^{\circ} \mathrm{C}$ with an increasing but not significant trend from 1987 to $2015\left(y=0.037 x-56.590 ; R^{2}=0.088\right)$ leading to particularly strong spat falls in 2002 and 2006, and again in 2010 (Fig. 3). Mean temperature rather than maximum temperature correlated positively with the likelihood of observing spatfalls. This effect was consistently
$0.04 \mathrm{~m}^{2}$. Lower panel sea surface temperatures in List tidal basin. Bold line shows the mean of measurements in July and August taken during daytime cruises (means were calculated from 13 measurements on average) and the shaded area encompasses the maximal and minimal values measured in the corresponding period. Dotted horizontal line indicates assumed $18^{\circ} \mathrm{C}$ threshold for spawning (see Diederich et al. 2005)

observed for spat falls in general (binomial GLM: mean temperature Deviance $(d f=1$, residual $d f=25)=4.629$, Likelihood Ratio Test $P=0.031)$ and when only strong spat falls were considered (binomial GLM: mean temperature Deviance $(d f=1$, residual $d f=25)=6.860$, Likelihood Ratio Test $P=0.009$ ). Nevertheless, there was no recruitment observed in 2007 and 2008, after which the population declined. This can be regarded as the beginning of the adjustment phase.

\section{Winter incursions}

Recruitment recurred in 2009, however, after a row of 13 mild winters, sheets of ice mechanically disturbed oyster beds and reefs, and, with freezing conditions at intertidal beds, mortality was high compared to previous winters (Büttger et al. 2011). Mortality affected all age classes but no cohort was wiped out completely. The winter 2009/2010 began with ice floes on December 20th and floating ice sheets were abundant with short interruptions until March 5th. Ice occurred also in the next two winters in February-March. This lasted only over 15 and $14 \mathrm{~d}$, respectively. Mortality was high again but recruitment resumed in the summers in between. Together, the three ice winters caused an intermittent incursion and a reset in population size 
Fig. 4 Size-frequency (\%) distributions of $C$. gigas near Munkmarsch harbor, not including spat of the year $(<20 \mathrm{~mm})$. Often recruits of the previous year dominated numerically, and sizes of $>200 \mathrm{~mm}$ were present after 2005

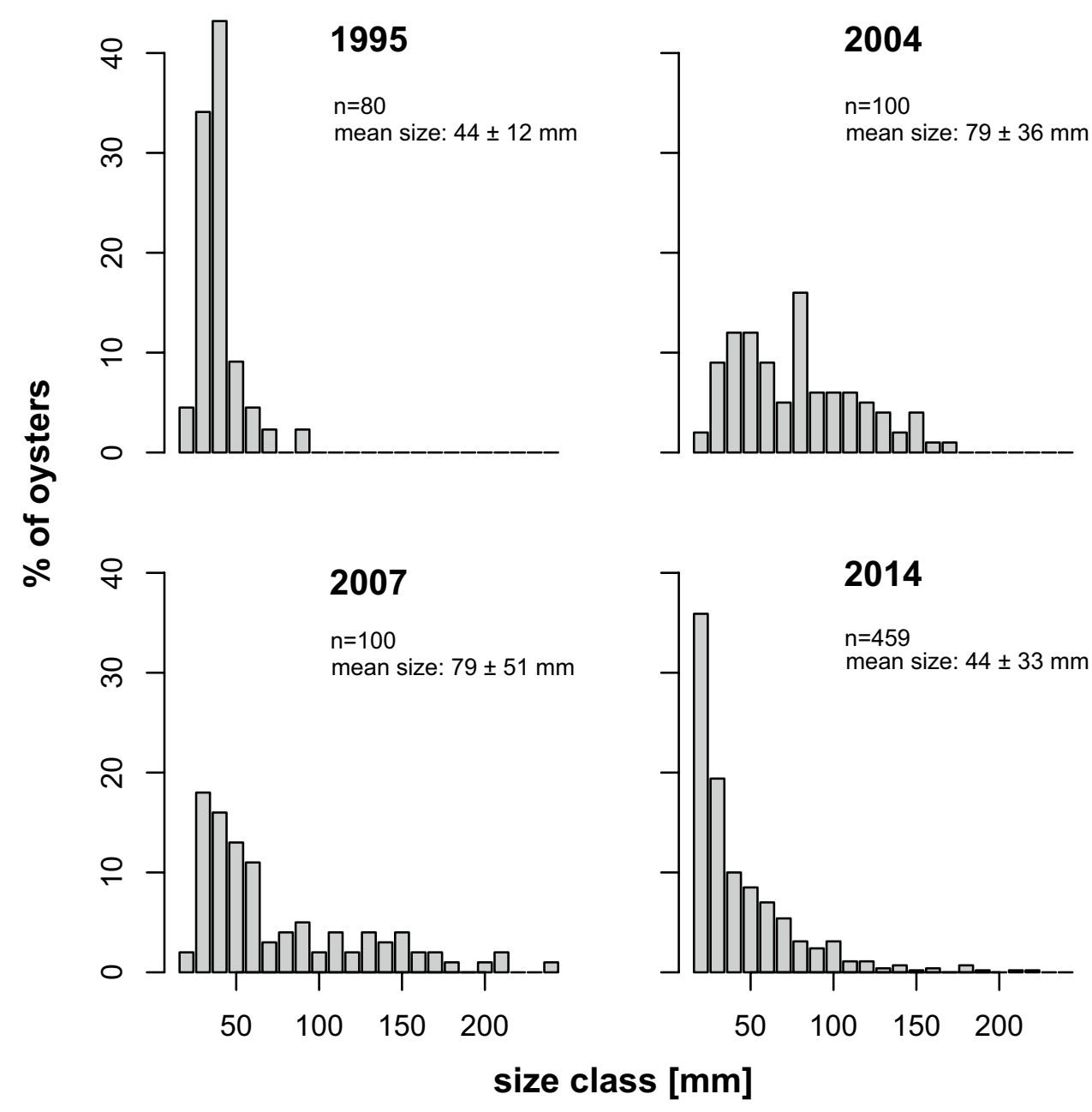

(Fig. 3), but left ample substrate for new settlement in the form of empty shells.

\section{Recovery and overall dynamics}

Since 2013 winters were mild again. Shell size distribution in 2014 was dominated by juveniles from the two previous years (Fig. 4). Earlier cohorts caused no spikes in distribution from 2014, and very large individuals were few compared to 2007. Population size increased exponentially for a second time, reaching maximum density in 2015 with more than $2500 \mathrm{~m}^{-2}$ and exceeding the previous boom of 2007 but at smaller average size. The lack of recruitment in 2015 and very low recruitment in 2016, however, may indicate continued adjustment phase.

In conclusion, the total dynamics over 26 years since first settlement of $C$. gigas on mussel beds near Sylt can be divided into 11 years with rather low and variable abundance (establishment phase), two intervals (7 and 4 years) of exponential population growth (expansion phase), separated by two years without recruitment and three consecutive ice winters that together led to a strong population decline. Recruitment did, however, resume during the phase with ice winters and might have mitigated the losses due to winter mortality. Highest abundance was observed in the last but one year; however, concomitant recruitment failure suggests that adjustment phase rebounds.

\section{Conservative bed area}

Based on observations on the ground and aerial photographs (see Fig. 2 and Büttger et al. 2014), positions and area occupied by beds of mussels and oysters in the tidal basins of Sylt seem to be rather conservative, regardless of whether composed of a mono-dominance of mussels or a co-dominance of mussels with oysters. This observation was supported by an unsuspected side effect of a field experiment with six artificially created plots covered with oysters and mussels (Fig. 2). From 2008 to 2016 these artificial square beds lost merely $11 \pm 4 \%$ of their original area-in spite of three ice winters in between-and none of the squares expanded. However, due to recruitment since 


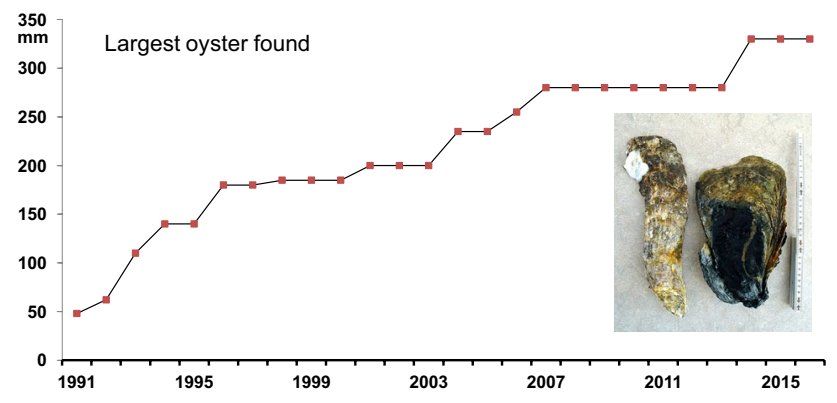

Fig. 5 Maximum size (longest diameter in $\mathrm{mm}$ ) of Pacific oysters encountered in the tidal basins of Sylt from 1991 to 2015 shown cumulatively. Inset shows longest and largest $C$. gigas found (scale $30 \mathrm{~cm}$; see also Table 1)

Table 2 Longest (Puan Klent, July 2014) and largest in terms of weight (Königshafen, March 2016) individual of Crassostrea gigas found near Sylt (see also inset Fig. 5)

\begin{tabular}{lcr}
\hline Oyster parameter & Longest & Largest \\
\hline Shell & & \\
Max. length (mm) & 330 & 254 \\
Max. width (mm) & 95 & 150 \\
Max. height (mm) & 50 & 55 \\
Below sediment surface (mm) & 190 & 180 \\
Dry weight $\left(3 \mathrm{~d}\right.$ at $80^{\circ} \mathrm{C}$; g) & 412 & 1071 \\
Soft body wet weight $($ cooked; g) & 61 & 75 \\
Dry weight $\left(3 \mathrm{~d}\right.$ at $80^{\circ} \mathrm{C}$; g) & 10 & 18 \\
Total wet weight with enclosed water $(\mathrm{g})$ & 758 & 1482 \\
\hline
\end{tabular}

2010, oyster abundance on the experimental beds tripled from $300 \pm 197$ to $805 \pm 240 \mathrm{~m}^{-2}, n=6$, and mussel abundance increased from $741 \pm 257$ to $930 \pm 313 \mathrm{~m}^{-2}, n=6$. It also suggests that oyster abundances developed in similar manner on different beds, and overall abundance during the last 26 years can be extrapolated to the approximate population size of feral oysters in the Wadden Sea around Sylt.

\section{Life span}

From an oyster's perspective, 26 years of invasion may be rather short. The maximum shell size encountered has increased through the entire period, suggesting that some oysters of the early 1990 s were still alive in the 2010 s (Fig. 5). These old individuals weigh up to $1.5 \mathrm{~kg}$ or attain a length of up to $330 \mathrm{~mm}$, and were anchored deep in the sediment (Table 2). Large size, thick shell and partly buried position may contribute to life spans of two decades (or maybe more), because no predators (except man) can be expected to open such big shells and dislocations by currents and waves are hardly possible. Fast upright growth also prevents burial and constitutes an advantage where crowded. However, young oysters growing upon large ones may eventually overtop and then hamper food intake of their basibionts. Accordingly, the largest oysters found usually showed little overgrowth by attached oysters.

\section{Discussion}

Native oysters Ostrea edulis were harvested from wild beds in the northern Wadden Sea until 1925 when the overexploited stock could no longer support commercial use, and the population died out in the 1950s (Neudecker 1990; Seaman and Ruth 1997; Lotze 2005). However, occasionally $O$. edulis were encountered between 1992 and 1995 at low tide level and below. Initially, the oyster farm at Sylt tried to raise this species as well but soon gave up (Thomas Neudecker, perscomm). Presumably, some of these oysters were scattered in the wild but no population became established. The once native oyster beds occurred from low tide level down to about $9 \mathrm{~m}$ depth (Möbius 1877). Thus, the feral Pacific oyster population with emerging reefs $\pm 0.7 \mathrm{~m}$ around low tide level is overlapping only marginally with the former range of $O$. edulis.

In the twentieth century, the NW-Pacific Crassostrea gigas emerged as 'global champion' of oyster growers and was introduced to almost all temperate and subtropical coasts, except East-Asia where it came from and NEAmerica to avoid interference with native $C$. virginica (Chew 1990; Shatkin et al. 1997; Ruesink et al. 2005; Padilla 2010; Beck et al. 2012). C. gigas has been successful because of its wide tolerance to environmental conditions, thriving in the intertidal and having high fecundity (Korringa 1976; Quayle 1988). These advantages for oyster farmers were also ideal predispositions of $C$. gigas spreading from sea-based oyster farms into coastal ecosystems. In addition to disclosing the role of adaptive traits, the introductions to so many coasts (i.e., Ruesink et al. 2005; Troost 2010) now offer a unique opportunity to compare invasion trajectories with respect to resistance, accommodation and integration processes in the various recipient ecosystems. In the following, this comparison is conducted stepwise from introduction and establishment, to expansion and adjustment phase (see Fig. 1).

\section{Introduction and establishment}

Since the annual imports of Pacific oysters for farming at Sylt had started, 15 years elapsed before high $\left(>1000 \mathrm{~m}^{-2}\right)$ feral densities occurred. Diederich et al. (2005) could show that successful reproduction was bound to a few summers with sufficiently high temperatures $\geq 18^{\circ} \mathrm{C}$. However, after 4 years larvae dispersed and settled on wild mussel beds. 
Regular stocking of oysters in the farm circumvented the hurdle of unpredictable temperature conditions for establishment by maintaining propagule pressure. One million densely packed oysters at the farm site may have also facilitated the fertilization rate in the tidal waters. Furthermore, only $50 \%$ of the high tide volume of water is exchanged in the tidal basin per semi-diurnal cycle (Gätje and Reise 1998), allowing for retention of planktonic larvae. Finally, abundant mussel beds up- and downstream of the oyster farm offered ample settling sites for oyster larvae at suitable depth in this sedimentary environment.

This combination of favorable prerequisites made the establishment of a feral population around Sylt almost inevitable, and could have been predicted from previous invasions elsewhere in cold waters. The time lag between first introduction and first establishment varied considerably between invaded coastal regions. At the American NW-coast, Pacific oyster introductions commenced in 1912 and first settlement in the wild happened 13 years later (Quayle 1988). In Tasmania, introductions since 1947 gave rise to a feral population 9 years later (Bourne 1979). At the Atlantic coast of southern France, introductions since 1968 were followed by wild settlement already 3 years later (Maurin and LeDantec 1979), while further north at Brittany this took more than 20 years (Lejart and Hily 2011). In the Oosterschelde estuary (SW Netherlands), introductions commenced in 1964 and first settlement happened after 11 years (Smaal et al. 2009). Only at the Swedish coast, where spat was introduced in 1973-1976, establishment took much longer with feral populations observed in 2007 (Wrange et al. 2010). However, it remains questionable whether these feral populations are direct descendents of farmed oysters or rather represent the invasion front from more southern populations unless population genetic studies will be performed.

It seems that first establishment in the wild after the start of sea-based farming was primarily temperature driven. Given the inherent temporal and spatial variability in this parameter, it was like playing 'ecological roulette' with oyster establishment bound to happen sooner or later (compare with Carlton and Geller 1993). Once the temperature hurdle was overcome, the almost global distribution of $C$. gigas after a century of introductions suggests that this species with its combination of invasive traits (wide tolerance to physical factors, fast growth, high fecundity, large size and longevity) has encountered little resistance by recipient ecosystems. Nevertheless, establishment phases with low abundances over several years (11 around Sylt) seem to be common, and in several cases have not yet developed further or showed signs of exponential growth. On rocky shores, abundances have generally remained rather low (i.e., Ruesink 2007; Robinson et al. 2005; Krassoi et al. 2008; Kochmann et al. 2013), although localized reefs have developed in parts of southern England (Herbert et al. 2016). This also applies to cold sedimentary coasts in Scandinavia (Wrange et al. 2010; Dolmer et al. 2014; Holm et al. 2015). On British coasts, field trials with $C$. gigas derived from hatcheries in British Columbia, commenced in 1967 and yet high abundances are confined to just a few estuaries (Herbert et al. 2016).

Repeated introductions may have circumvented extinctions after initial establishment. However, also longevity could overcome recruitment failures over many years. At the coast of Argentina, a singular introduction occurred in 1982 because farming was soon abandoned. Nevertheless, an established feral population was observed 10 years later (Escapa et al. 2004), which must be attributed to survivors of the initial introduction. In England, $C$. angulata, which later was recognized as a Taiwanese strain of $C$. gigas (Boudry et al. 1998), was introduced in 1890 and survived in small populations until 1970 (Humphreys et al. 2014; Herbert et al. 2016). Again, this can only be explained by long life spans of a few individuals because no regular spat falls and high abundances were reported.

It can be concluded that ready establishment of $C$. gigas on so many coasts has been made easy by sea-based farming practices with regular introductions of spawning individuals compared to irregular yachts and ships as vectors of introductions. The invasive traits of $C$. gigas made an almost universal establishment inevitable and coastal ecosystems resistant to the invasion of this oyster are few. However, expansion phases leading to exponential growth of feral populations are less ubiquitous.

\section{Expansion phase}

A transition from less than one hundred oysters per $\mathrm{m}^{2}$ to well over 1000 oysters per $\mathrm{m}^{2}$ is not common at all. It has not occurred at exposed rocky shores but is a phenomenon of sheltered sedimentary shores where there are larger particles such as gravel, pebbles and shell, rocky outcrops, boulders, harbor walls or biogenic reefs such as mussel beds. Comparisons between coasts are hampered by different methods of quantification in the field, i.e., as percentage of area covered by oysters, as total wet weight or individual numbers per unit area. These are not convertible. At Sylt, abundance of 100 individuals $\mathrm{m}^{-2}$ usually amounts to about $25 \%$ cover, $>400 \mathrm{~m}^{-2}$ to $100 \%$ cover, and $1000 \mathrm{~m}^{-2}$ or more comprise large oysters with shells often partly fused to one another or to empty shells, and with attached younger ones on top, forming a complex reef structure above and below sediment surface, weighing $>30 \mathrm{~kg} \mathrm{~m}^{-2}$ (Fig. 6).

The development of such high-density reefs is made possible by larval gregariousness during settlement and by circumventing the larviphagy of adult oysters (Diederich 2006; Tamburri et al. 2007; Troost et al. 2008a, b; 
Fig. 6 Edge of crowded oyster reef with lateral fusion of valves and attached young oysters on top in the Wadden Sea (Munkmarsch at Sylt) (left) and in the Yellow Sea (Daebudo Island, Korea). Scale bar $100 \mathrm{~mm}$ for both photographs
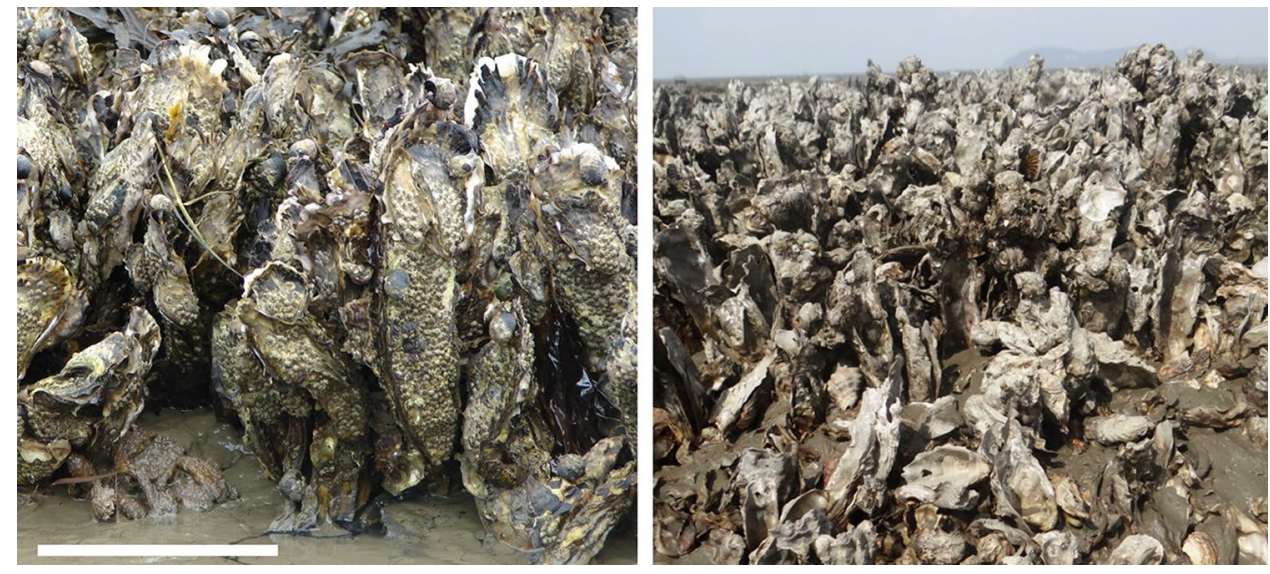

Troost 2010). We could show that the proximity of contiguous oysters facilitates larval settlement by conducting an experiment with settlement plates in the centre of artificial rings composed of densely packed mussels, oysters or both species mixed in approximately equal proportion (for further description see Kochmann et al. (2008), and see circular patches at the seaward side of the wild bed in 2008 shown in Fig. 2). Panels surrounded by oysters had significantly more oysters spat than panels surrounded by mussels (unpublished data). Such gregariousness of larval settlement facilitates crowding on oyster reefs and also leads to stable bed areas.

More positive feedbacks may play a role in exponential population growth. The elevated three-dimensional reef structure offers firm substrate for settlement in good feeding positions, and reefs protect individual oysters against dislocation by waves or currents, and probably against predators. Lejart \& Hily (2011) mention abundances $>1000 \mathrm{~m}^{-2}$ for estuarine habitats in Brittany, Cognie et al. (2006) wet weight up to $45 \mathrm{~kg} \mathrm{~m}^{-2}$ south of Brittany, and Laugen et al. (2015) $>1000 \mathrm{~m}^{-2}$ as upper range for shallow water sites at Swedish fjords. These high abundances may be rather patchy or insular due to limiting attachment for settling oyster larvae. However, in the Wadden Sea and presumably in the nearby Oosterschelde estuary, abundances $>1000 \mathrm{~m}^{-2}$ on former mussel beds have become a common feature since the 2000s (Markert et al. 2010, 2013; Nehls et al. 2011; Dolmer et al. 2014; Walles et al. 2015 and this study). Apart from harbor walls and low-lying coastal revetments at low-to-moderate wave exposure, such high abundances occur on mussel beds or sites of former mussel beds with abundant empty shells. In the western Dutch Wadden Sea, oysters also covered sites where mussel beds had been overexploited and devastated by a previous fishery (van Stralen et al. 2012; van den Ende et al. 2016). Mussel beds provide the substratum for large and dense Pacific oyster reefs in the Wadden Sea at positions ideal for epibenthic suspension feeders. On a global scale, the Wadden Sea has developed into a hot spot of feral C. gigas thanks to its extensive mussels beds.

There seems to be a close match between the ecological niches of oysters and mussels in this coastal region. However, the match is not perfect. Oysters are few and small at the highest parts of mussel beds (own unpubl data; Waser et al. 2016), and there are still regions with mussel beds in the Wadden Sea where oysters have not achieved high abundances (Nehls et al. 2011; van Stralen et al. 2012; van den Ende et al. 2016). Also at the coast of SE-England, in Limfjorden (Denmark) and Kattegat (Sweden), Pacific oysters occur on sediment together with mussels but oyster abundances were one order of magnitude lower than in the Wadden Sea (Groslier et al. 2014; Holm et al. 2015, 2016; Norling et al. 2015; Hollander et al. 2015; Herbert et al. 2016). Insufficient food supply has been suggested as an explanation but the exact mechanisms preventing high oyster densities in these areas are still unclear.

The presence of mussel beds alone is, however, not sufficient to explain the development towards abundances $>1000$ per $\mathrm{m}^{2}$. Temperature is crucial for the global distribution of $C$. gigas (Carrasco and Barón 2010), and for spawning a wide range of 16 to 34 with an optimal range of 20 to $25^{\circ} \mathrm{C}$ has been suggested (Shatkin et al. 1997). The role of high summer temperatures for spawning and larval development has been shown to trigger recruitment success in C. gigas around Sylt (Diederich et al. 2005). From 2001 onwards, mean July-August water temperatures exceeded $17^{\circ} \mathrm{C}$ (except in 2011) and recruitment success became rather regular. Particularly strong spat fall events coincided with peaks of temperature maxima (Fig. 3). Regular recruitment success may be a precondition for crowding to occur with oysters settling upon oysters, generating reefs which become independent of the underlying mussel beds. In conclusion, the transition from establishment phase with low abundances to expansion phase with abundances up to two orders of magnitude higher in the Wadden Sea was aided by common mussel beds on sheltered sediments and 
high regional summer temperatures (Wiltshire and Manly 2004; van Aken 2008; Witte et al. 2010) that allowed regular recruitment with oysters settling upon oysters.

The rare occurrence of $C$. gigas reefs with abundances $>1000 \mathrm{~m}^{-2}$ on global scale needs to be investigated further. High-density reefs also occur on mud flats in the native region but individuals tend to remain smaller than in the Wadden Sea (Fig. 6). In the Yellow Sea, these reefs are not grounded on mussel beds but on scattered boulders, often laid out by artisanal fisherman. Boulders may become buried by sedimentation while the oysters grow upwards and subsequent generations settle upon their predecessors. So far it seems that $C$. gigas reefs are confined to sedimentary environments at low tide level with firm substrate for attachment. Further prerequisites are frequent recruitment and probably eutrophic conditions with strong tidal flushing.

\section{Adjustment phase}

After peak density in the feral oyster population around Sylt in 2007, decline commenced with two consecutive summers without recruitment and a series of ice winters starting 2009/2010 when many oysters died. Comparing autumn and spring abundances, Büttger et al. (2011) estimated winter mortality to about $90 \%$ with all size classes of C. gigas affected. However, most shells remained in place and long-lasting effects on the oyster population were not to be expected. For the same winter, Strand et al. (2012) estimated 66\% winter mortality in the adjacent Danish Wadden Sea, while no enhanced mortality was noted further south in the Dutch Wadden Sea (van Stralen et al. 2012). As can be expected, winter mortality at Scandinavian coasts increased with latitude with up to $100 \%$ in the course of that unusually severe winter (Strand et al. 2012). Thus, Pacific oyster populations at higher latitudes may experience occasionally dramatic crashes when hit by harsh winter conditions.

However, the long-term ice record for the German North Sea coast shows a general decline in frequency since the mid 1980s (Schmelzer et al. 2016). When oyster abundance was still low and most individuals young, the similarly harsh ice winter of 1995/1996 caused only a mortality of 34\% (Reise 1998). Also Büttger et al. (2011) recorded lower winter mortality at sites with lower oyster abundances. They suggested that the high-density population at northern Sylt might have been more vulnerable to sheets of ice moving back and forth with the tides. The following two winters (2010 to 2012) brought some ice cover as well, and recovery of the feral population was delayed. In view of the long period with mild winters (1996 to 2009), the strong winter incursion in the invasion trajectory of Pacific oysters around Sylt should be regarded as a singular event but could have lasting effects by selecting for cold resistant oysters. During the establishment phase, the number of farmed and feral oysters remained in the same order of magnitude and extended gene flow from hatcheries to the feral population could have prevented selection for local adaptations (Moehler et al. 2011). After the expansion phase, however, strong selective pressure such as ice winters or disease on the numerically dominant feral population may facilitate local evolution and influence the extent of future frost and disease-associated mortalities (Sussarellu et al. 2015; Wendling and Wegner 2015; Wendling et al. 2017).

Recruitment failure in 2007, 2008 and 2015 coincided with particularly high abundances of resident oysters. Three years are not yet sufficient to prove this case; however, future research should address density dependence as a driver in the population dynamics of $C$. gigas. According to our own qualitative observations in adjacent areas with lower oyster density, these recruitment failures were a phenomenon confined to the tidal basins of Sylt. Since oyster spat was not only lacking within reefs but also on scattered clumps of oysters, we assume that food shortage or larviphagy is unlikely to explain recruitment failure. More likely could be epidemic diseases arising at high population density, affecting larvae or oysters soon after metamorphosis in particular. Size-frequency distributions (Fig. 4 and see Schmidt et al. 2008; Walles et al. 2015) suggest high mortality in the first year of benthic life. Although shore crabs Carcinus maenas and starfish Asterias rubens have been observed to prey on small oysters (own unpubl. experiments), predation is unlikely to account for complete recruitment failure in the intertidal zone. Crabs preferred young mussels over young oysters and starfish were almost absent from intertidal flats around Sylt.

However, pathogenic bacteria and viral infections resembling the widespread summer disease syndrome (SDS) are known to affect populations in adjacent regions (Watermann et al. 2008; Thieltges et al. 2013; Wendling et al. 2014; Mortensen et al. 2016) and the recent recruitment failure and population decline (2015/2016) were associated with increased loads of oyster herpes virus (OsHv1, unpublished data). This may suggest that disease can also play an important role for the population dynamics of feral oysters on Sylt. With global warming and continued crowding in a large host population, it is to be expected that $C$. gigas around Sylt will become more frequently exposed to disease agents (see Fey et al. 2015; Sweet and Bateman 2015; Travers et al. 2015). Oyster diseases can affect different life stages but mortalities are usually highest in early life (Le Roux et al. 2016), where also evolutionary responses are most efficient and can further contribute to establishment success (Wendling and Wegner 2015).With the development of a large feral oyster population around Sylt, we 
predict an adjustment phase with diseases taking a higher toll, causing strong density-dependent fluctuations around a mean density of about 1000 oysters $\mathrm{m}^{-2}$ on the reefs, thus resembling the type II trajectory in Fig. 1.

\section{Summary and outlook}

The observed invasion of introduced Pacific oysters in the tidal basins of Sylt during the first 25 years can be seen as a representative model of feral oyster invasions in a global context: Establishment was facilitated by repeated introductions. During the 1990s, recruitment was sporadic because summer temperatures were often too cold for spawning and overall abundance remained low. Since the 2000s warmer summers became normal and recruitment more regular. This triggered the exponential expansion phase. At particularly high oyster densities, recruitment failures were observed, indicating the beginning of an adjustment phase. An incursion of ice winters caused high oyster mortality but had little effect on bed area, and exponential population growth resumed once again, achieving abundances of more than two thousand oysters per $\mathrm{m}^{2}$ before recruitment failure recurred.

Once the vagaries of early oyster life have been overcome, high longevity of established individuals constitutes a backbone of population persistence. Large individuals also offer suitable attachment for new generations, initiating a positive feedback which may lead to reef building. Reefs will eventually exceed maximum individual life spans and then further support population persistence. In this way, the Pacific oyster is progressively anchoring itself deeper into the recipient ecosystem, and over time will leave a conspicuous calcareous signal in the geology of the Wadden Sea as well. With the accretion of shell material, reef area may slowly expand but may also raise reefs above $4 \mathrm{~h}$ of tidal emergence which seems beyond the physiological range of $C$. gigas.

The invasion trajectory observed at Sylt may be representative for most of the Wadden Sea region and adjacent estuaries. However, strong winter incursions have been shared only with the Scandinavian coasts further north. Abundances well over $1000 \mathrm{~m}^{-2}$ are shared with feral populations in sheltered bays at the French Atlantic coast. Scandinavian and British feral populations in suitable habitats may locally achieve similar abundances in the wake of global warming. Pacific oysters on exposed rocky shores seem to remain at relatively low abundances, perhaps caused by resident predators (Ruesink 2007).

For the future, we expect the density on oyster reefs to fluctuate around about 1000 oysters $\mathrm{m}^{-2}$ mainly due to density-dependent epidemic diseases in conjunction with continued climatic warming. Large populations as well as transferring oysters for farming purposes could also facilitate the spread of diseases, precluding a phase of population stability. Evolutionary adaptations by disease agents and by the oysters will further contribute to continuous change as will the globalization of coastal biota by ongoing introductions of nonnative species.

As long as sea-based farming of exotic oysters is regarded as acceptable, there was and will be no chance to prevent establishment of feral populations. This is evident from the almost global distribution achieved by $C$. gigas, and could have been expected after the establishment on the NW-coast of America early in the twentieth century. The development towards conspicuous oyster reefs on top of mussel beds in the Wadden Sea World Heritage Site appears to be a high price paid to satisfy a gourmet market. Analyzing the causes and impacts of this globally replicated development can thus provide a lesson for future mariculture practices.

Acknowledgements We are grateful to Felix Briem, Annika Cornelius, Stefan Görlitz, Meike Honens, Tobias Mayr, Ana Lokmer, Raja Wetuschat, Kaibil Escobar Wolf for their research on Pacific oysters around Sylt and sharing their results with us. Susanne Diederich and Roger J.H. Herbert helped with valuable comments on an earlier draft of this manuscript. Christian Hass and Tobias Dolch helped with aerial photographs. We thank four reviewers who helped to improve text and figures. For dredging subtidal oysters we thank the crew from research catamaran MYA, Alfred Resch and Kai von Bohlen. We also thank the Schleswig-Holstein Office of the Wadden Sea National Park for general support and funding mussel and oyster monitoring within the framework of the Trilateral Monitoring and Assessment program (TMAP). Since 1998, Alfred Wegener Institute, Helmholtz Centre for Polar and Marine Research gave generous support to our ongoing research on invasive oysters.

\section{Compliance with ethical standards}

Funding This study was funded by Alfred Wegener Institute Helmholtz Centre for Polar- and Marine Research, Coastal Ecology by supplying a retired scientist (first author) with splendid working conditions.

Conflict of interest No grants were received from companies, except a general support from the Schleswig-Holstein Office of the Wadden Sea National Park for mussel and oyster bed monitoring given to BioConsult SH. We declare to have no conflict of interests.

Ethical approval All applicable international, national, and/or institutional guidelines for the care and use of animals were followed.

Open Access This article is distributed under the terms of the Creative Commons Attribution 4.0 International License (http:// creativecommons.org/licenses/by/4.0/), which permits unrestricted use, distribution, and reproduction in any medium, provided you give appropriate credit to the original author(s) and the source, provide a link to the Creative Commons license, and indicate if changes were made. 


\section{References}

Beck MW, Brumbaugh RD, Airoldi L et al (2012) Oyster reefs at risk and recommendations for conservation, restoration, and management. Bioscience 61:107-116. doi:10.1525/ bio.2011.61.2.5

Bilio M, Niermann U (2004) Is the comb jelly really to blame for it all? Mnemiopsis leidyi and the ecological concerns about Caspian Sea. Mar Ecol Prog Ser 269:173-183. doi:10.3354/ meps 269173

Boudry P, Heurtebise S, Collet B, Cornette F, Gérard A (1998) Differentiation between populations of the Portuguese oyster, Crassostrea angulata (Lamark) and the Pacific oyster Crassostrea gigas (Thunberg), revealed by mtDNA RFLP analysis. J Exp Mar Biol Ecol 226:279-291. doi:10.1016/S0022-0981(97)00250-5

Bourne N (1979) Pacific oysters, Crassostrea gigas Thunberg, in British Columbia and the South Pacific islands. In: Mann R (ed) Exotic species in mariculture. The MIT Press, Cambridge, pp 1-53

Branch GM, Steffani CN (2004) Can we predict the effects of alien species? A case-history of the invasion of South Africa by Mytilus galloprovincialis (Lamarck). J Exp Mar Biol Ecol 300:189-215. doi:10.1016/j.jembe.2003.12.007

Büttger H, Nehls G, Witte S (2011) High mortality of Pacific oysters in a cold winter in the North-Frisian Wadden Sea. Helgol Mar Res 65:525-532. doi:10.1007/s10152-011-0272-1

Büttger H, Nehls G, Stoddard P (2014) The history of intertidal blue mussel beds in the North Frisian Wadden Sea in the 20th century: Can we define reference conditions for conservation targets by analyzing aerial photographs? J Sea Res 87:91-102. doi:10.1016/j.seares.2013.12.001

Carlton JT, Geller JB (1993) Ecological roulette: the global transport of nonindigenous marine organisms. Science 261:78-82. doi:10.1126/science.261.5117.78

Carrasco MF, Barón PJ (2010) Analysis of the potential geographic range of the Pacific oyster Crassostrea gigas (Thunberg, 1793) based on surface seawater satellite data and climate charts: the coast of South America as a study case. Biol Invasions 12:2597-2607. doi:10.1007/s10530-009-9668-0

Chew K (1990) Global bivalve shellfish introductions. World. Aquaculture 21:9-22

Cognie B, Haure J, Barillé (2006) Spatial distribution in a temperate coastal ecosystem of the wild stock of the farmed oyster Crassostrea gigas (Thunberg). Aquaculture 259:249-259. doi:10.1016/aquaculture.2006.05.037

Crooks JA (2005) Lag times and exotic species: the ecology and management of biological invasions in slow-motion. Ecoscience 12:316-329. doi:10.2980/i1195-6860-12-3-316.1

Crooks JA, Rilov G (2009) The establishment of invasive species. In: Rilov G, Crooks JA (eds) Biological invasions in marine ecosystems. Springer, Berlin Heidelberg, pp 173-175. Ecological Studies ISSN 0070-8356

Diederich S (2005a) Invasion of Pacific oysters (Crassostrea gigas) in the Wadden Sea: competitive advantage over native mussels. Dissertation, Kiel University

Diederich S (2005b) Differential recruitment of introduced Pacific oysters and native mussels at the North Sea coast: coesistence possible? J Sea Res 53:269-281. doi:10.1016/j. seares.2005.01.002

Diederich S (2006) High survival and growth rates of introduced Pacific oysters may cause restrictions on habitat use by native mussels in the Wadden Sea. J Exp Mar Biol Ecol 328:211227. doi:10.1016/j.jembe.2005.07.012

Diederich S, Nehls G, van Beusekom JEE, Reise K (2005) Introduced Pacific oysters (Crassostrea gigas) in the northern
Wadden Sea: invasion accelerated by warm summers? Helgol Mar Res 59:97-106. doi:10.1007/s10152-004-0195-1

Dolmer P, Holm MW, Strand A, Lindegarth S, Bodvin T, Norling P, Mortensen S (2014) The invasive Pacific oyster, Crassostrea gigas, in Scandinavian coastal waters: A risk assessment on the impact in different habitats and climate conditions. Fisken og Havet 2-2014:1-67

Drinkwaard AC (1999a) History of cupped oyster in European coastal waters. Aquaculture. Europe 15(7):14-41

Drinkwaard AC (1999b) Introductions and developments of oysters in the North Sea area: a review. Helgoländer Meeresuntersuchungen 52:301-308. doi:10.1007/BF02908904

Escapa M, Isacch JP, Daleo P et al (2004) The distribution and ecological effects of the introduced oyster Crassostrea gigas (Thunberg, 1793) in northern Patagonia. J Shellfish Res 23:765-772

Eschweiler N (2011) Foes and friends: Integration of invasive alien oysters into the epibenthic community of the Wadden Sea. Dissertation, Kiel University

Essink K, Dekker R (2002) General patterns in invasion ecology tested in the Dutch Wadden Sea: the case of a brackish-marine polychaetous worm. Biol Invasions 4:359-368 doi:10.102 3/A:1023692825663

Fey SB, Siepielski AM, Nusslé S et al (2015) Recent shifts in the occurrence, cause, and magnitude of animal mass mortality events. PNAS 11(4):1083-1088. doi:10.1073/pnas.1414894112

Gätje Ch, Reise K (eds) (1998) Ökosystem Wattenmeer: Austausch-, Transport- und Stoffumwandlungsprozesse. Springer, Berlin

Groslier T, Christensen HT, Davids J et al (2014) Status oft he Pacific oyster Crassostrea gigas (Thunberg, 1793) in the western Limfjord, Denmark-five years of population development. Aquat Invasions 9:175-182. doi:10.3391/ai.2014.9.2.06

Herbert RJH, Humphreys J, Davies CJ, Roberts C, Fletcher S, Crowe TP (2016) Ecological impacts of non-native Pacific oysters (Crassostrea gigas) and management measures for protected areas in Europe. Biodivers Conserv 25:2835-2865. doi:10.1007/ s10531-016-1209-4

Hollander J, Blomfeldt J, Carlsson P, Strand Ã (2015) Effects of the alien Pacific oyster (Crassostrea gigas) on subtidal macrozoobenthos communities. Mar Biol 162:547-555. doi:10.1007/ s00227-014-2604-6

Holm MW, Davids JK, Dolmer P, Vismann B, Hansen BW (2015) Moderate establishment success of Pacific oyster, Crassostrea gigas, on a sheltered interitidal mussel bed. J Sea Res 104:1-8. doi:10.1016/j.seares.2015.07.009

Holm MW, Davids JK, Dolmer P et al (2016) Coexistence of Pacific oyster Crassostrea gigas (Thunberg, 1793) and blue mussels Mytilus edulis Linnaeus, 1758 on sheltered intertidal bivalve bed? Aquat Invasions 11:155-165. doi:10.3391/ai.2016.11.2.05

Humphreys J, Herbert RJH, Roberts C, Fletcher S (2014) A reappraisal of the history and economics of the Pacific oyster in Britain. Aquaculture 428-429:117-124. doi:10.1016/j. aquaculture.2014.02.034

Johnston EL, Piola RF, Clark GF (2009) The role of propagule pressure in invasion success. In: Rilov G, Crooks JA (eds) Biological invasions in marine ecosystems. Springer Berlin Heidelberg: 133-151. Ecological Studies ISSN 0070-8356

Kochmann J, Buschbaum C, Volkenborn N, Reise K (2008) Shift from native mussels to alien oysters: Differential effects of ecosystem engineers. J Exp Mar Biol Ecol 364:1-10. doi:10.1016/j. jembe.2008.05.015

Kochmann J, O’Beirn F, Yearsley J, Crowe TP (2013) Environmental factors associated with invasion: modelling occurrence data from a coordinated sampling programme for Pacific oysters. Biol Invasions 15:2265-2279. doi:10.1007/s10530-013-0452-9

Korringa P (1976) Farming of cupped oysters of the genus Crassostrea. Elsevier Sci Publ Comp, Amsterdam 
Krassoi FR, Brown KR, Bishop MJ, Kelaher BP, Summerhayes S (2008) Condition-specific competition allows coexistence of competitively superior exotic oysters with native oysters. J Animal Ecol 77:5-15. doi:10.1111/j.1365-2656.2007.01316.x

Lackschewitz D, Menn I, Reise K (2002) Das marine Ökosystem um Sylt unter veränderten Klimabedingungen. In: Daschkeit A, Schottes P (eds) Klimafolgen für Mensch und Küste am Beispiel der Nordseeinsel Sylt. Springer, Berlin, pp 153-180

Laugen AT, Hollander J, Obst M, Strand Ã (2015) The Pacific oyster (Crassostrea gigas) invasion in Scandinavian coastal waters: impact on local ecosystem services. In: Canning-Clode J (ed) Biological invasions in changing ecosystems: vectors, ecological impacts, management and prediction. De Gruyter Open, pp 230-252

Le Roux F, Wegner KM, Polz MF (2016) Oysters and vibrios as a model for disease dynamics in wild animals. Trends Microbiol 24:568-580. doi:10.1016/j.tim.2016.03.006

Lejart M, Hily C (2011) Differential response of bentic macrofauna to the formation of novel oyster reefs (Crassostrea gigas, Thunberg) on soft and rocky substrate in the intertidal of the Bay of Brest, France. J Sea Res 65:84-93. doi:10.1016/j.seares.2010.07.004

Lockwood JL, Robinson OI (2014) The impacts of invasive species on coastal marine ecosystems. In: Maslo B, Lockwood JL (eds) Coastal conservation. Cambridge University Press, Cambridge pp 245-264. ISBN 978-I-107-60674-6

Lotze HK (2005) Radical changes in the Wadden Sea fauna and flora over the last 2,000 years. Helgol Mar Res 59:71-83. doi:10.1007/ s10152-004-0209-Z

Markert A, Wehrmann A, Kröncke I (2010) Recently established Crassostrea-reefs versus native Mytilus-beds: differences in ecosystem engineering affects the macrofaunal communities (Wadden Sea of Lower Saxony, southern German Bight). Biol Invasions 12:15-32. doi:10.1007/s10530-009-9425-4

Markert A, Esser W, Frank D, Wehrmann A, Exo K-M (2013) Habitat change by the formation of alien Crassostrea-reefs in the Wadden Sea and its role as feeding sites for waterbirds. Est Coast Shelf Sci 131: 41-51. doi:10.1016/j.ecss.2013.08.003

Maurin C, LeDantec (1979) The culture of Crassostrea gigas in France. In: Mann R (ed) Exotic species in mariculture. The MIT Press, Cambridge, pp 106-122

Möbius K (1877) Die Auster und die Austernwirthschaft. Parey, Berlin

Moehler J, Wegner KM, Reise K, Jacobsen S (2011) Invasion genetics of Pacific oyster Crassostrea gigas shaped by aquaculture stocking practices. J Sea Res 66:256-262. doi:10.1016/j. seares.2011.08.004

Mortensen S, Strand A, Bodvin T et al (2016) Summer mortalities and detection of ostreid herpesvirus microvariant in Pacific oyster Crassostrea gigas in Sweden and Norway. Dis Aquat Org 117:171-176. doi:10.3354/dao02944

Nehls G, Diederich S, Thieltges DW, Strasser M (2006) Wadden Sea mussel beds invaded by oysters and slipper limpets: competition or climate control? Helgol Mar Res 60:135-143. doi:10.1007/ s10152-006-0032-9

Nehls G, Büttger H, Ruth M (2011) Miesmuschelmonitoring und Miesmuschelmanagement im Nationalpark "Schleswig-Holsteinisches Wattenmeer" 1997-2009. Report BioConsult SH, Husum and Obere Fischereibehörde, Kiel, Germany

Neudecker T (1990) The history of the former German oyster fishery and mariculture: 400 years of crown law on oyster (4.2.1587). Dt hydrogr Z, Erg-H B 22:518-525

Norling P, Lindegarth M, Lindegarth S, Strand Ã (2015) Effects of live and post-mortem shell structures of invasive Pacific oysters and native blue mussls on macrofauna and fish. Mar Ecol Prog Ser 518:123-138. doi:10.3354/meps11044
Olyarnik SV, Bracken MES, Byrnes JE, Hughes AR, Hultgren KM, Stachowicz J (2009) Ecological factors affecting community invasibility. In: Rilov G, Crooks JA (eds) Biological invasions in marine ecosystems. Springer, Berlin Heidelberg pp 215-238. Ecological Studies ISSN 0070-8356

Padilla DK (2010) Context-dependent impacts of a non-native ecosystem-engineer, the Pacific oyster Crassostrea gigas. Integr Comp Biol 50:213-225. doi:10.1093/ich/icq080

Quayle DB (1988) Pacific oyster culture in British Columbia. Can Bull Fish Aquat Sci 218:1-241

Reise K (1998) Pacific oysters invade mussel beds in the European Wadden Sea. Senckenbergiana maritima 28:167-175. doi: $10.1007 / \mathrm{BF} 03043147$

Reise K, Lackschewitz D (1998) Benthos des Wattenmeeres zwischen Sylt und Rømø. In: Gätje C, Reise K (eds) Ökosystem Wattenmeer. Springer, Berlin, pp 55-64

Reise K, Olenin S, Thieltges DW (2006) Are aliens threatening European aquatic coastal ecosystems? Helgol Mar Res 60:77-83. doi:10.1007/s10152-006-0024-9

Rilov G, Crooks JA (2009) Biological invasions in marine ecosystems. Springer, Berlin Heidelberg Ecological Studies ISSN 0070-8356

Robinson TB, Griffiths CL, Tonin A et al (2005) Naturalized populations of oysters, Crassostrea gigas along the South African coast: Distribution, abundance and population structure. J Shellfish Res 24:443-450

Ruesink JL (2007) Biotic resistance and facilitation of a non-native oyster on rocky shores. Mar Ecol Prog Ser 331:1-9. doi:10.3354/ meps331001

Ruesink JL, Lenihan HS, Trimble AC et al. (2005) Introduction of non-native oysters: ecosystem effects and restoration implications. Annu Rev Ecol Evol Syst 36:643-689. doi:10.1146/ annurev.ecolsys.36.102003.152638

Schmelzer N, Holfort J, Weisse, R (2016) Sea ice. In: Quante M, Colijn F (eds) North Sea region climate change assessment. Springer open, pp 122-124. doi:10.1007/978-3-319-39745-0

Schmidt A, Wehrmann A, Dittmann S (2008) Population dynamics of the invasive Pacific oyster Crassostrea gigas during the early stages of an outbreak in the Wadden Sea. Helgol Mar Res 62:367-376. doi:10.1007/s10152-008-0125-8

Seaman MNL, Ruth M (1997) The molluscan fisheries of Germany. In: U.S. Dep. Commer., NOAA Tech. Rep. NMFS 129:57-84

Shatkin G, Shumway SA, Hawes R (1997) Considerations regarding the possible introduction of the Pacific oyster (Crassostrea gigas) to the Gulf of Maine: A review of global experience. J Shellfish Res 16:463-477

Simberloff D, Gibbons L (2004) Now you see them, now you don't: Population crashes of established introduced species. Biol Invasions 6:161-172. doi:10.1023/B:BINV.0000022133.49752.46

Smaal AC, Kater BJ, Wijsman J (2009) Introduction, establishment and expansion of the Pacific oyster Crassostrea gigas in the Oosterschelde (SW Netherlands). Helgol Mar Res 63:75-83. doi:10.1007/s10152-008-0138-3

Strand $\AA$, Blanda E, Bodvin T et al (2012) Impact of an icy winter on the Pacific oyster (Crassostrea gigas Thunberg, 1793) populations in Scandinavia. Aquat Invasions 7:433-440. doi:10.3391/ ai.2017.7.3.014

Strasser M (1999) Mya arenaria - an ancient invader of the North Sea coast. Helgoländer Meeresunters 52:309-324. doi:10.1007/ BF02908905

Sussarellu R, Huvet A, Lapègue S, Quillen V et al (2015) Additive transcriptomic variation associated with reproductive traits suggest local adaptation in a recently settled population of the Pacific oyster, Crassostrea gigas. BMC Genomics 16:808. doi:10.1186/s12864-015-1972-8 
Sweet MJ, Bateman KS (2015) Diseases in marine invertebrates associated with mariculture and commercial fisheries. J Sea Res 104:16-32. doi:10.1016/j.seares.2015.06.016

Tamburri MN, Zimmer RK, Zimmer CA (2007) Mechanisms reconciling gregarious larval settlement with adult cannibalism. Ecol Monogr 77:255-268. doi:10.1890/06-1074

Thieltges DW, Engelsma MY, Wendling CC, Wegner KM (2013) Parasites in the Wadden Sea food web. J Sea Res 82:122-133. doi:10.1016/j.seares.2012.06.002

Travers M-A, Miller KB, Roque A, Friedman CS (2015) Bacterial diseases in marine bivalves. J Invert Path 131:11-31. doi:10.1016/j. jip.2015.07.010

Troost K (2010) Causes and effects of a highly successful marine invasion: case-study of the introduced Pacific oyster Crassostrea gigas in continental NW European estuaries. J Sea Res 64:145165. doi:10.1016/j.seares.2010.02.004

Troost K, Kamermans P, Wolff WJ (2008a) Larviphagy in native bivalves and an introduced oyster. J Sea Res 60:157-163. doi:10.1016/j.seares.2008.04.006

Troost K, Veldhuizen R, Stamhuis EJ, Wolff WJ (2008b) Can bivalve veligers escape feeding currents of adult bivalves? J Exp Mar Biol Ecol 358:185-196. doi:10.1016/j.jembe.2008.02.009

van Aken HM (2008) Variability of the water temperature in the Western Wadden Sea on tidal to centennial scales. J Sea Res 60:227-234. doi:10.1016/j.seares.2008.09.001

van Stralen M, Troost K, van Zweeden C (2012) Ontwikkling van banken Japanse oesters (Crassostrea gigas) op droogvallende platen in de Waddenzee. Marinx Rapport 2012.101

van den Ende D, Brummelhuis E, van Zweeden C, van Asch M, Troost K (2016) Mosselbanken en oesterbanken op droogvallende platen in de Nederlandse kustwateren in 2015: bestand en arealen. IMARES rapport C168/15, Wageningen UR

Walles B, Mann R, Ysebaert T, Troost K, Herman PMJ, Smaal AC (2015) Demography of the ecosystem engineer Crassostrea gigas, related to vertical reef accretion and reef persistence. Est Coast Shelf Sci 154:224-233. doi:10.1016/j.ecss.2015.o1.006

Waser AM, Deuzeman AK, waKangeri AK, van Winden E, Postma J et al (2016) Impact on bird fauna of a non-native oyster expanding into blue mussel beds in the Dutch Wadden Sea. Biol Conserv 202:39-49. doi:10.1016/j.biocon.2016.08.007

Watermann BT, Herlyn M, Daehne B et al (2008) Pathology and mass mortality of Pacific oysters, Crassostrea gigas (Thunberg), in 2005 at the East Frisian coast, Germany. J Fish Dis 31:621-630. doi:10.1111/j.1365-2761.2008.00904.x

Wendling CC, Wegner KM (2015) Adaptation to enemy shifts: rapid resistance evolution to local Vibrio spp. in invasive Pacific oysters. Proc R Soc B 282:2244. doi:10.1098/rspb.2014.2244

Wendling CC, Batista FM, Wegner KM (2014) Persistence, seasonal dynamics and pathogenic potential of Vibrio communities from Pacific oyster hemolymph. PLoS One 9(4):e94256. doi:10.1371/ journal.pone.0094256

Wendling CC, Fabritzek AG, Wegner KM (2017) Population-specific genotype $\mathrm{x}$ genotype $\mathrm{x}$ environment interactions in bacterial disease of early life stages of Pacific oyster larvae. Evolut Appl, in press. doi:10.1111/eva.12452

Wiltshire KH, Manly BFJ (2004) The warming trend at Helgoland roads, North Sea: phytoplankton responses. Helgol Mar Res 58:269-273. doi:10.1007/s10152-004-0196-0

Witte S, Buschbaum C, van Beusekom JEE, Reise K (2010) Does climatic warming explain why an introduced barnacle finally takes over after a lag of more than 50 years? Biol Invasions 12:3579 3589. doi:10.1007/s10530-010-9752-5

Wrange A-L, Valero J, Harkestad LS, Strand Ø (+ 5 authors) (2010) Massive settlement of the Pacific oyster, Crassostrea gigas, in Scandinavia. Biol Invasions 12:1145-1152. doi:10.1007/ s10530-009-9535-Z 